\title{
Using chemical compositions of sediments to constrain methane seepage dynamics: A case study from Haima cold seeps of the South China Sea
}

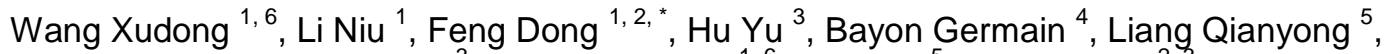 \\ Tong Hongpeng ${ }^{3}$, Gong Shanggui ${ }^{1,6}$, Tao Jun ${ }^{5}$, Chen Duofu ${ }^{2,3}$
}

${ }^{1}$ CAS Key Laboratory of Ocean and Marginal Sea Geology, South China Sea Institute of Oceanology, Chinese Academy of Sciences, Guangzhou 510301, China

${ }^{2}$ Laboratory for Marine Mineral Resources, Qingdao National Laboratory for Marine Science and

Technology, Qingdao 266061, China

${ }^{3}$ Shanghai Engineering Research Center of Hadal Science and Technology, College of Marine

Sciences, Shanghai Ocean University, Shanghai 201306, China

${ }^{4}$ IFREMER, Unité de Recherche Géosciences Marines, Laboratoire Géophysique et Enregistrements Sédimentaires, F-29280Plouzané, France

${ }^{5}$ MLR Key Laboratory of Marine Mineral Resources, Guangzhou Marine Geological Survey, China

Geological Survey, Guangzhou 510070, China

${ }^{6}$ University of Chinese Academy of Sciences, Beijing 100049, China

* Corresponding author : Dong Feng, email address : $\underline{\text { feng@scsio.ac.cn }}$

\begin{abstract}
:
Cold seeps frequently occur at the seafloor along continental margins. The dominant biogeochemical processes at cold seeps are the combined anaerobic oxidation of methane and sulfate reduction, which can significantly impact the global carbon and sulfur cycles. The circulation of methane-rich fluids at margins is highly variable in time and space, and assessing past seepage activity requires the use of specific geochemical markers. In this study, we report multiple sedimentary proxy records for three piston gravity cores (QDN-14A, QDN-14B, and QDN-31) from the Haima seep of the South China Sea (SCS). By combining total organic carbon (TOC), total inorganic carbon (TIC), total nitrogen (TN), total sulfur (TS), acid insoluble carbon and sulfur isotope ( $\delta 13$ Corganic carbon and $\delta 34$ Sacid-insoluble), and $\delta 34 S$ values of chromium reducibility sulfur ( $\delta 34 S C R S$ ), as well as carbon isotopes of TIC (ס13CTIC) in sediments, our aim was to provide constraints on methane seepage dynamics in this area. We identified three sediment layers at about $260-300 \mathrm{~cm}, 380-420 \mathrm{~cm}$ and $480-520 \mathrm{~cm}$ sediment depth, characterized by particular anomalies of low $\delta 13 C$ TIC values and high TS content, high TS and CRS contents, and high $\delta 34$ Sacid-insoluble and $\delta 34$ SCRS values, respectively. On this basis, we propose that these sediment horizons correspond to distinct methane release events preserved in the sediment record. While the exact mechanisms accounting for the presence (or absence) of these particular geochemical signals in the sediment are not known, we propose that they correspond to variations in methane flux and their duration through time. Overall, our results suggest that sedimentary carbon and sulfur and their isotopes are useful tracers for better understanding of methane seepage dynamics over time.
\end{abstract}




\section{Graphical abstract}

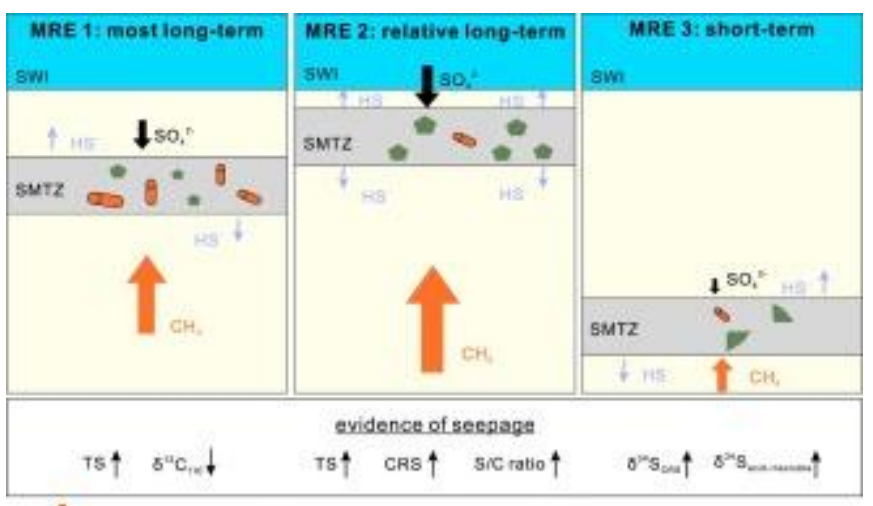

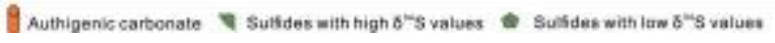

\section{Highlights}

- Sediments from Haima cold seeps have variable compositions. AOM caused high $\delta^{34} \mathrm{~S}_{\mathrm{CRS}}$ and low $\delta^{13} \mathrm{C}_{\mathrm{TIC}}$ values, and high CRS contents. AOM indicators of sediments are variable under variable methane flux and duration. Three methane release events were identified in the seep site.

Keywords : Cold seep, Anaerobic oxidation of methane, Carbon and sulfur isotopes, South China Sea 


\section{Introduction}

In the marine environment, continental margins play an important role in the carbon cycle, accounting for more than $80 \%$ of organic carbon burial in the sediment (Berner, 1989; Tesi et al., 2007). The presence of organic matter, and subsequent degradation during diagenesis, leads to widespread seepage of hydrocarbon (mainly methane) fluids (Campbell et al., 2002; Campbell, 2006; Suess, 2014).

In cold seep environments, the anaerobic oxidation of methane (AOM, equation 1) is mediated by a syntrophic consortium of anaerobic methanotrophic archaea and sulfate reducing bacteria. This key biogeochemical process occurs at the sulfate-methane transition zone (SMTZ), and plays a major role in the marine geochemical cycling of carbon and sulfur (Jørgensen, 1982; Holmer et al., 2001; Wijsman et al., 2001; Nauhaus et al., 2005). Previous studies on seepage-related processes mainly focused on authigenic minerals (equations 2, 3, 3a, 3b, 4 and etc., Hu et al., 2015; Feng et al., 2016; Raven et al., 2016) and sediment pore waters (Maciej, 2012; Luo et al., 2013). Upon formation in the sediment, authigenic minerals such as calcite, aragonite, barite and pyrite can archive useful information that reflects the surrounding geochemical environment, and hence can be used to characterize methane seep activity (Dickens, 2001; Han et al., 2004, 2008, 2013; Peckmann and 
Thiel, 2004; Bayon et al., 2009, 2013, 2015; Mazumdar et al., 2009, 2011; Tong et al., 2013; Feng et al., 2014, 2015a,b).

$$
\begin{gathered}
\mathrm{CH}_{4}+\mathrm{SO}_{4}{ }^{2-} \rightarrow \mathrm{HCO}_{3}{ }^{-}+\mathrm{HS}^{-}+\mathrm{H}_{2} \mathrm{O} \\
\mathrm{Ca}^{2+}+2 \mathrm{HCO}_{3}{ }^{-} \rightarrow \mathrm{CaCO}_{3}+\mathrm{CO}_{2}+\mathrm{H}_{2} \mathrm{O} \\
\mathrm{Fe}^{2+}+\mathrm{HS}^{-}+\mathrm{HCO}_{3}{ }^{-} \rightarrow[\mathrm{FeS}]+\mathrm{H}_{2} \mathrm{O}+\mathrm{CO}_{2} \\
{[\mathrm{FeS}]+\mathrm{S}_{\mathrm{n}}{ }^{2-} \rightarrow \mathrm{FeS} 2+\mathrm{S}_{(\mathrm{n}-1)}{ }^{2-} \quad(\text { rapid })} \\
{[\mathrm{FeS}]+\mathrm{H}_{2} \mathrm{~S} \rightarrow \mathrm{FeS}_{2}+\mathrm{H}_{2} \quad \text { (indirectly) }} \\
\mathrm{Ba}^{2+}+\mathrm{SO}_{4}{ }^{2-} \rightarrow \mathrm{BaSO}_{4}
\end{gathered}
$$

While it is well known that physical, chemical, and biological conditions at seeps can change significantly with time (Greinert, 2008; Solomon et al., 2008; Schneider von Deimling et al., 2011), it still remains difficult to determine changes in past seepage activity through time (Feng et al., 2015a). The closing and opening of gas migration pathways, sea level and climate changes, and past episodes of dissociation and/or formation of gas hydrate (Kvenvolden, 1993; Aharon et al., 1997; Judd et al., 2002; Teichert et al., 2003) can act as forcing mechanisms controlling cold seep activity through time (Tong et al., 2013). Unfortunately, the sediment pore water can only record current (or recent) biogeochemical processes. In addition, authigenic minerals precipitate under specific conditions in cold seep sediments, and are often absent in low and high methane flux environments (Luff and Wallmann, 2003, Luff et al., 2004). In fact, a few studies have shown that sediment cores recovered from fluid seepage areas can serve as continuous archives that can be used to reconstruct the evolution of past seepage activity (Tribovillard et al., 2006, 2012, 2013; Bayon et al., 
2007; Peketi et al., 2015).

The circulation of methane-rich fluids can significantly alter the primary sulfur isotopic composition of marine sediments (Jørgensen et al., 2004; Li et al., 2016; Lin Q. et al., 2016; Gong et al., 2018). In this study, we report an extensive set of data for total carbon (TC), total organic carbon (TOC), total nitrogen (TN), and total sulfur (TS), acid-insoluble carbon and sulfur isotope, chromium reducibility sulfur (CRS = $\mathrm{FeS}_{2}, \mathrm{~S}^{\circ}$ and remaining part of $\mathrm{Fe}_{3} \mathrm{~S}_{4}$, Jørgensen et al., 2004) and $\delta^{34} \mathrm{~S}_{\mathrm{CRS}}$ as well as carbon isotopes of TIC, on sediment cores collected from the Haima site, an active cold seep site recently discovered in the northeast of South China Sea (SCS; Feng et al., 2018). The motivation of this study was to confirm the existence of cold fluid seepage in the study area and provide further constraints on the impact of seepage activity on the carbon and sulfur cycles in marine sediments.

\section{Materials and methods}

Three sediment cores, QDN-14A (845 cm-long), QDN-14B (820 cm-long), and QDN-31 (745 cm-long), were recovered using the Haiyang-4 (Apr. 3th, 2015) from a water depth of $1400 \mathrm{~m}$ at the Haima seeps of the northwest SCS (Fig. 1). Core QDN-14A and core QDN-14B were collected from the same location. The combination of overpressure and high paleo-geothermal gradient, as well as faulting or diapirism, resulted in the generation, migration and accumulation of natural gases across the sedimentary column (Zhu et al., 2009). Gas hydrate layers, authigenic carbonate deposits, and various cold-seep communities were recovered from the study 
area (Liang et al., 2017).

After extraction of pore waters, sediment samples were collected at a 5-cm resolution, sealed in sterile bags on board, prior to being freeze-dried and powdered manually using an agate mortar in the onshore laboratory for elemental and bulk isotope analyses. Because cores QDN-14A and QDN-14B were recovered from the same location, some analyses were conducted on either of the two cores: chromium reducible sulfur extraction and isotope testing were performed on core QDN-14B only, while carbon and oxygen isotopic ratios for total inorganic carbon were conducted on core QDN-14A sediments only. See supplementary material for details.

Sulfate $\left(\mathrm{SO}_{4}{ }^{2-}\right)$, calcium $\left(\mathrm{Ca}^{2+}\right)$ and magnesium $\left(\mathrm{Mg}^{2+}\right)$ concentrations were determined on a Dionex ICS-5000 ${ }^{+}$ion chromatograph with an analytical precision of $<2 \%$ at the South China Sea Institute of Oceanology (SCSIO), Chinese Academy of Sciences (CAS). The anions $\left(\mathrm{SO}_{4}{ }^{2-}\right)$ and cations $\left(\mathrm{Ca}^{2+}\right.$ and $\left.\mathrm{Mg}^{2+}\right)$ were determined by 500 folds and 100 folds dilution, respectively, using ultra-pure water.

TC, TOC, TN, TS contents were measured using a Heraeus CHN-O Rapid elemental analyzer at Guangzhou Institute of Geochemistry (GIG), CAS. After TC measurement, carbonate was removed using $10 \% \mathrm{v} / \mathrm{v} \mathrm{HCl}$. After completion of the reaction, deionized water was added and the residue was centrifuged, rinsed (X3) and subsequently dried at $60{ }^{\circ} \mathrm{C}$ prior to TOC determination. The TIC content of the sediment was calculated by substracting TOC from TC. Precision and accuracy of the TOC, TIC, TS and TN were better than $3 \%$.

CRS was extracted for concentration and isotopic measurements according to a 
modified version of the Cr-reduction method (Canfield et al., 1986). The extraction of the CRS from the sediment was done at SCSIO, CAS. Measurement reproducibility of the CRS contents was better than $2 \%$. For isotopic measurements at the Louisiana State University (LSU), about $2 \mathrm{mg} \mathrm{Ag}_{2} \mathrm{~S}$ and $1-2 \mathrm{mg} \mathrm{V}_{2} \mathrm{O}_{5}$ (as a catalyst) were added to the sediment into a small tin boat, converted to $\mathrm{SO}_{2}$ at $980{ }^{\circ} \mathrm{C}$ with an Elemental Analyzer (EA), and a continuous flow model was used to carry out the sulfur isotope test in the Thermo-Electron Delta V Plus Advantage mass spectrometer. The standard deviation of the $\delta^{34} \mathrm{~S}$ analysis is $\pm 0.2 \%$, and the results are normalized to the VCDT standard.

Grain-size composition was determined at a 5-cm depth resolution along studied sediment cores using a MASTERSIZE 2000 Laser Particle Size Analyzer at SCSIO, CAS, after removal of organic matter and carbonate with $10 \% \mathrm{H}_{2} \mathrm{O}_{2}$ and $10 \% \mathrm{v} / \mathrm{v} \mathrm{HCl}$, respectively. Prior to analysis, a solution of 0.05 mol/l sodium metaphosphate was also added to prevent aggregation of fine particles. The relative error on grain-size measurements inferred from duplicate analyses was less than $2 \%$.

Carbonate-free sediment samples were analyzed for carbon and sulfur isotopic analyses at the LSU. Approximately $0.2 \mathrm{~g}$ of sediment were treated with $2 \mathrm{~mol} / \mathrm{L} \mathrm{HCl}$ in an ultrasonic oscillator, and the obtained residues were rinsed with deionized water. Measured $\delta^{13} \mathrm{C}$ and $\delta^{34} \mathrm{~S}$ compositions are expressed relative to the VPDB and VCDT standards, respectively. The analytical accuracy on $\delta^{13} \mathrm{C}$ and $\delta^{34} \mathrm{~S}$ measurements were better than $0.1 \%$ and $0.2 \%$, respectively.

For carbon and oxygen isotopic measurements of TIC, sediment samples were 
allowed to react with phosphoric acid. The resulting $\mathrm{CO}_{2}$ was imported into a MAT253-Gasbench mass spectrometer for analysis at the LSU. All results are expressed relative to the VPDB standard, with an analytical accuracy on both $\delta^{13} \mathrm{C}$ and $\delta^{18} \mathrm{O}$ better than $0.1 \%$.

\section{Results}

\subsection{Ion concentration of pore water and bulk CNS contents of sediment}

The data are given in Supplementary Tables 1-4. The dissolved $\mathrm{SO}_{4}{ }^{2-}, \mathrm{Ca}^{2+}, \mathrm{Mg}^{2+}$ concentrations in the three cores, and DIC concentration and $\delta^{13} \mathrm{C}_{\mathrm{DIC}}$ of QDN-14A and -14B are shown in Fig. 2A (the data of QDN-14A and QDN-14B are from Hu et al., in revision). Sediment core profiles of TOC, TIC, TN and TS contents are plotted in Fig. 2B.

The average TOC contents of the three sediment cores are similar. TOC contents for core QDN-14A, QDN-14B and QDN-31 range from 0.51 to $0.88 \mathrm{wt} . \%$ (0.70 wt.\% on average; $\mathrm{N}=42$ ), 0.18 to 1.40 wt. $\%$ (mean 0.85 wt. $\% ; \mathrm{N}=67$ ) and 0.47 to 1.20 wt. $\%$ (mean 0.87 wt.\%; $\mathrm{N}=38$ ), respectively.

The TIC contents of the three studied cores also display a similar trend downcore, starting from relatively high values ( $3 \mathrm{wt} . \%)$ in sub-surface sediments, followed by a drop towards lower values ( 1 wt.\%) and further increase with sediment depth. TIC content for core QDN-14A, QDN-14B and QDN-31 ranges from 0.29 to $3.69 \mathrm{wt} . \%$, 0.57 to $3.74 \mathrm{wt} . \%$ and 0.66 to $3.58 \mathrm{wt} . \%$, respectively.

The downcore evolution of TN and TS contents in the three cores display 
different patterns, especially between $250 \mathrm{~cm}$ and $430 \mathrm{~cm}$ depth, which could relate to differences in grain size (see Fig. 4). Compared to core QDN-31, TN values in core QDN-14A and core QDN-14B are significantly reduced in this sediment interval while TS displays an opposite trend.

The $\mathrm{C} / \mathrm{N}$ molar ratios show little variation downcore except for a few samples between 405 and $425 \mathrm{~cm}$, but S/C ratios in the three cores markedly differ. The S/C ratio of core QDN-14A and core QDN-14B is much higher than in core QDN-31, especially between $260 \mathrm{~cm}$ and $525 \mathrm{~cm}$.

\subsection{Chromium reducible sulfur (CRS) and $\delta^{34} S_{C R S}$}

The depth profiles for CRS concentrations in core QDN-14B and core QDN-31 and associated sulfur isotopic compositions are shown in Fig. 3. CRS concentrations vary from $0.07 \mathrm{wt} . \%$ to $0.99 \mathrm{wt} . \%$ in core $\mathrm{QDN}-14 \mathrm{~B}$ (the maximum value being encountered in the $390-410 \mathrm{~cm}$ depth interval) and from $0.01 \mathrm{wt} . \%$ to $0.45 \mathrm{wt} . \%$ in core QDN-31. The $\delta^{34} \mathrm{~S}_{\mathrm{CRS}}$ display large variability in core $\mathrm{QDN}-14 \mathrm{~B}$, with values ranging from $-30.6 \%$ to $5.4 \%$ (the highest $\delta^{34} \mathrm{~S}_{\mathrm{CRS}}$ being observed at $525 \mathrm{~cm}$ depth). In contrast, the $\delta^{34} \mathrm{~S}_{\mathrm{CRS}}$ fluctuate between $-46.6 \%$ to $-28.6 \%$ in core QDN-31.

\subsection{Median particle diameter}

The depth profiles for the median particle diameter of sediments in core QDN-14B and core QDN-31 are shown in Fig. 4. The median particle diameter of core QDN-31 remains essentially constant with an average value of $7.6 \mu \mathrm{m}$. However, 
the median particle diameter of sediments in core QDN-14B shows dramatic changes between $300 \mathrm{~cm}$ and $450 \mathrm{~cm}$ with values up to of $82 \mu \mathrm{m}$, which clearly indicate the presence of coarse-grained particles.

\subsection{Acid-insoluble C, S isotope}

The isotopic compositions of the acid-insoluble residual carbon (i.e. the organic carbon fraction) and sulfur of sediments from cores QDN-14B and QDN-31 are shown in Fig. 5. Core QDN-31 displays relatively constant $\delta^{13} \mathrm{C}$ values, while core QDN-14B is characterized by an excursion towards low $\delta^{13} \mathrm{C}$ values between $245 \mathrm{~cm}$ and $425 \mathrm{~cm}$ depth (as low as $-25.9 \%$ at $405 \mathrm{~cm}$ ).

The sulfur isotopic composition of acid-insoluble sulfides and CRS both show similar trends (Figs. 3B and 5B), indicating that the TS signal in the sediment is mainly derived from solid iron sulfide phases. The $\delta^{34} \mathrm{~S}_{\text {acid-insoluble }}$ of sediments in core QDN-14B display positive values between $485 \mathrm{~cm}$ and $525 \mathrm{~cm}$ depth, while the

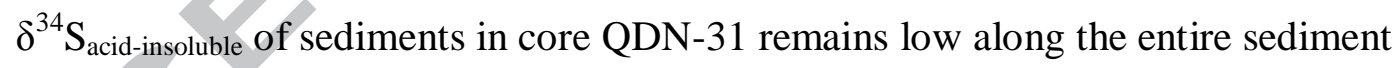
core.

\subsection{Inorganic $C$, $O$ isotopes of core $Q D N-14 A$}

The $\delta^{13} \mathrm{C}_{\text {TIC }}$ values vary greatly from $-10.3 \%$ to $0.4 \%$, and the most negative value appears at $285 \mathrm{~cm}$ (Fig. 6A). The $\delta^{18} \mathrm{O}_{\text {TIC }}$ values vary from $-3.0 \%$ o to $0.6 \%$. 


\section{Discussion}

\subsection{Evidence for present and past methane release events (MREs)}

Based on the geochemical characteristics reported above for the studied sediment cores, three particular sediment horizons can be identified, which we presumably attribute to present and past sedimentary markers associated with the circulation of methane-rich fluids in the sediment. Below, we discuss each of these three distinct sediment layers, which we refer to as indicators of methane release events (MREs).

MRE 1: In the upper part of the sediment, methane reacts with sulfate, at the modern SMTZ located at about $300 \mathrm{~cm}$ depth. The benthic dissolve methane fluxes were $62 \mathrm{mmol} \mathrm{m}^{-2} \mathrm{yr}^{-1}$ and $4.0 \mathrm{mmol} \mathrm{m}^{-2} \mathrm{yr}^{-1}$ at sites QDN-14A and QDN-14B, respectively (Hu et al., 2018). The position of the SMTZ can be also inferred from pore water sulfate and DIC concentrations, as well as with the occurrence of negative $\delta^{13} \mathrm{C}_{\text {DIC }}$ values (Figs. 2A and 6A). In core QDN-14A, this sedimentary horizon is associated with low $\delta^{13} \mathrm{C}_{\mathrm{TIC}}$ values (between $-10.3 \%$ to $-7.3 \%$; Fig. $6 \mathrm{~A}$ ), lower than that of normal marine carbonates (about 0, Whiticar, 1999). In this study, the measurement of carbonate $\delta^{13} \mathrm{C}_{\mathrm{TIC}}$ values of bulk sediments suggests that they most likely represent a mixture between biogenic carbonate material (composed of benthic and planktonic foraminifera shells, $-0.2 \%{ }^{13} \mathrm{C}_{\mathrm{TIC}}<1.7 \%$. Fig. $6 \mathrm{~B}$; Ye et al., 2004; Wang et al., 2014) and methane-derived authigenic carbonate phases $\left(\delta^{13} \mathrm{C}_{\mathrm{TIC}}<\right.$ $-10.3 \%$ ). It is worth noting that the oxygen isotopes are correspondingly positive at this horizon, probably reflecting the destabilization of gas hydrates, which are particularly abundant (Liang et al., 2017). 
MRE 2: This interval corresponds to the sediment layer between $380 \mathrm{~cm}$ and 410 $\mathrm{cm}$, which we interpret as a paleo-SMTZ horizon. In suboxic marine sediments, sulfate reduction related to organic matter remineralization generally releases hydrogen sulfide into the pore water (Berner, 1970, 1984). In these settings, reduced sulfur and organic carbon contents typically show a positive correlation with an average S/C ratio of 0.36 (Berner, 1982). In contrast, in methane-rich environments, AOM dominates sulfate reduction and generate excess $\mathrm{HS}^{-}$at the depth of the SMTZ, leading to both precipitation of solid sulfide phases such as pyrite (CRS; Fig. 3A) and increase of bulk sediment S/C ratios (Fig. 2B). This process has been well studied in the Nankai Trough and northern SCS (Lim et al., 2011; Sato et al., 2012; Li et al., 2016). By analogy, the high $S / C$ ratios encountered in this sediment interval of core QDN-14B most likely indicate that they correspond to fossil horizon of a methane-rich environment.

MRE 3: This interval corresponds to the sediment layer between $485 \mathrm{~cm}$ and 525 $\mathrm{cm}$ depth, characterized by particularly high $\delta^{34} \mathrm{~S}$ values. In the near seafloor environment, the sulfur isotopic difference between dissolved sulfate and sulfide compounds is generally large (40-65\%; Böttcher et al., 2004; Jørgensen et al., 2004). However, the conversion process of hydrogen sulfide in pore water into pyrite only produces very small isotope fractionation ( 1\%; Wilkin and Barnes, 1996). The sulfur isotope value of CRS can be taken, to a first approximation, as a reliable estimate for the $\delta^{34} \mathrm{~S}$ signature of the hydrogen sulfide from which precipitated from in the pore water. Compared to the reference core, the $\delta^{34} \mathrm{~S}_{\mathrm{CRS}}$ values in core 
QDN-14B are much higher in this particular sediment interval (i.e. up 5.4\%o at $525 \mathrm{~cm}$ depth, hence about 50\% heavier than corresponding values in QDN-31; Fig. 3B), hence reflecting an isotopically enriched hydrogen sulfide of pore waters at the time of formation, most likely through AOM (Borowski et al., 2013).

4.2. The utility of AOM-related indicators in cold seep sediments and implication for methane seepage dynamics

In the above discussion, we showed that the presence of both present and former AOM horizons in the sediment, which we refer to as MREs, can be inferred from the use of distinct carbon- and sulfur-based proxies. Previous studies have shown that methane flux and the duration of fluid seepage were the two most important factors affecting bulk sediment geochemical characteristics at cold seeps (Luff and Wallmann, 2003; Luff et al., 2004; Wankel et al., 2010; Coffin et al., 2014; Hiruta et al., 2016). The preservation of the geochemical signals in marine sediment are highly dependent on changing physical, chemical and biological conditions in fluid seepage areas (Greinert, 2008; Solomon et al., 2008; Schneider von Deimling et al., 2011).

One striking particularity at cold seep settings is the precipitation of methane-derived carbonate phases characterized by extremely negative $\delta^{13} \mathrm{C}_{\mathrm{TIC}}$ signatures (Han et al., 2008; Feng et al., 2015b). However, authigenic carbonates can only precipitate under particular conditions: carbonate precipitation being most effective under conditions of sustained intermediate methane flow rates over several thousands of years. In contrast, formation of authigenic carbonate phases is strongly 
inhibited when methane fluxes are too low and too high (Luff and Wallmann, 2003;

Luff et al., 2004; Karaca et al., 2010). In addition to methane flux, dissolved methane concentrations, bioturbation and sedimentation rates are also likely to influence carbonate precipitation in cold seep sediments (Luff et al., 2004; Bayon et al., 2007, Li et al., 2016).

The application of sulfur isotopes to sedimentary pyrite in cold seep settings is being increasingly used for providing constraints sulfur biogeochemical processes (Jørgensen et al., 2004; Li et al., 2016; Lin Z. et al., 2016), but their interpretation remains complex due to large fractionation factors (Bottrell et al., 2009; Borowski et al., 2013). In seawater, the $\delta^{34} \mathrm{~S}$ composition of dissolved sulfate is about $21 \%$, while microbial sulfate reduction can result in an isotopic fractionation of up to $60 \%$ o (Jørgensen et al., 2004). Modern marine sediment can be viewed as open systems, but this is generally not the case for the deeper sediment column (Jørgensen et al., 2004; Peketi et al., 2012). There is a general relationship with the depth of the SMTZ and methane fluxes in marine sediments (Borowski et al., 1996). In environments characterized by low methane fluxes, the SMTZ is located deeper in the sediment column, with more restricted inputs from downward diffusing sulfate. In these environments, the sulfate replenishment rate from the above sub-surface sediment layers is generally lower than sulfate consumption rate at the SMTZ (Lin Q. et al., 2016). This effect can result in residual dissolved sulfate and associated hydrogen sulfide being characterized by a shift toward heavier sulfur isotopic compositions (Borowski et al., 1996; Jørgensen et al., 2004; Jørgensen and Parkes, 2010; Peketi et 
al., 2012, 2015). In contrast, in areas of high methane fluxes, the SMTZ is generally located in the near seafloor environment, where sulfate in pore waters can be replenished much more efficiently than in at deeper sediment depths. Under such conditions, the Rayleigh fractionation effect decreases and result in pyrite displaying relatively more depleted sulfur isotopic signatures (Peketi et al., 2012, 2015; Li et al., 2016; Lin Z. et al., 2016).

In addition to the sulfur isotopic composition of pyrite, the abundance of pyrite in the sediment can also provide useful information. In sediments, sulfide mineralization is an accumulative process (Borowski et al., 1996; Niewohner et al., 1998; Jørgensen et al., 2004). The content of solid sulfide phases in sediments is dependent on a variety of factors, such as the rate of hydrogen sulfide diffusion and the supply of reactive iron, as well as sedimentation rates (Borowski et al., 2013). Under the particular conditions of slow rates of hydrogen sulfide diffusion and efficient supply of reactive iron supply, the sedimentary CRS content can significantly increase (Li et al., 2016; Lin Z. et al., 2016).

Previous studies have suggested that AOM processes could simultaneously influence of the abundance of solid sulfide phases in sediments and their sulfur isotopic composition (Li et al., 2016). Strikingly, however, our results show that bulk sediment sulfide contents can be decoupled from the $\delta^{34} \mathrm{~S}$ profile at the studied site, with the highest sulfide contents (MRE 2) and the most positive value of $\delta^{34} \mathrm{~S}_{\mathrm{CRS}}$ (MRE 3) being encountered at different sediment depths. In fact, this observation has been already reported in previous studies (Jørgensen et al., 2004; Borowski et al., 
2013). The abundance of sulfide minerals in sediments can be affected by a number of factors (Borowski et al., 1996; Niewohner et al., 1998), in particular by changes in methane flux (Jørgensen et al., 2004). As shown above based on sulfur isotopes, the methane flux associated with the formation of MRE 3 was probably lower than for MRE 2. Meanwhile, we propose that the duration of MRE 3 was probably not long enough for a stable pyrite pool to form. Compared to MRE 3, the methane flux associated with MRE 2 was probably much higher, and presumably took place over a longer period of time. This hypothesis would explain the occurrence of high CRS contents in the sediment, but without any particular shift in heavier $\delta^{34} \mathrm{~S}_{\mathrm{CRS}}$ signatures during MRE 2.

Another interesting feature of our results is the carbon isotopic excursion of organic carbon towards negative values at about $405 \mathrm{~cm}$ (MRE 2), with a minimum value of $-25.9 \%$ of sediments from core QDN-14B (Fig. 5). Early diagenetic processes and carbon sources are the two main factors controlling the organic $\delta^{13} \mathrm{C}$ isotopic composition in marine sediments (Lehmann et al., 2002). From the seafloor

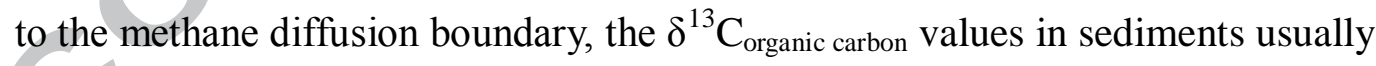
display a shift towards more low signatures with increasing sediment depth (Lehmann et al., 2002), mostly because of the preferential degradation during early diagenesis of organic compounds characterized by heavier isotopic compositions (proteins and carbohydrates), which can result in a $2 \%$ shift of $\delta^{13} \mathrm{C}_{\text {organic carbon }}$ (Kvenvolden, 1988; Borowski et al., 1996; Meyers, 1997; Freudenthal et al., 2001; Jørgensen et al., 2001; Lehmann et al., 2002). In normal marine environments (i.e. in areas not affected by 
methane seepage), organic matter mainly derives from both terrigenous and marine sources. The $\mathrm{C} / \mathrm{N}$ molar ratio of studied sediments suggest that organic matter in the study area mainly originates from marine sources. However, MRE 2 is characterized by anomalously high bulk sediment $\mathrm{C} / \mathrm{N}$ values, which, taken with evidence for coarser particle size (Figs. 2 and 4), point towards the presence of coarse-grained terrigenous organic matter in this particular sediment interval (Fig.4). While $\delta^{13} \mathrm{C}$ organic display near constant values over much of core QDN-31, with an average value (-21\%) typical of marine organic matter (-22 to -20\%o, Meyers, 1994; Ogrinc et

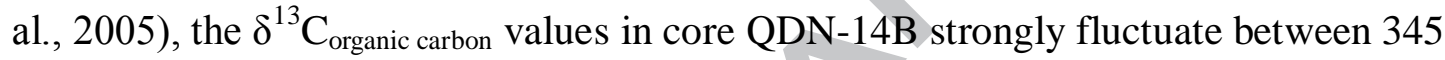
$\mathrm{cm}$ and $425 \mathrm{~cm}$ (with values as low as $-25.9 \%$ at $405 \mathrm{~cm}$ depth). The $\delta^{13} \mathrm{C}_{\text {organic carbon }}$ difference between the two cores reaches almost 5\%, and the effect of diagenetic processes is unlikely to reach this extent. Compared to the typical $\delta^{13} \mathrm{C}_{\text {org }}$ composition of marine sediments, the $\delta^{13} \mathrm{C}_{\text {org }}$ signature of terrigenous organic matter is comparatively often low (-27\%o, Meyers, 1997). Although further investigation is needed, we propose that the excursions towards lighter organic carbon isotopic signatures in core QDN-14B reflect localized input of terrigenous sediments.

Based on results from previous studies and our own findings, we summarize the combined effects of methane flux and duration of the three methane release events in the study area (Fig. 7). Cold seep activity is associated with changes in both methane flux and duration of fluid seepage, and this can significantly affect both carbon and sulfur biogeochemical cycling and cause a large range of associated geochemical indicators in the sediment. The combination of multiple geochemical indicators for 
carbon and sulfur cycling at cold seeps is required for a detailed and thorough assessment of methane seepage dynamics.

\section{Conclusion}

The sediments collected from the Haima methane seep area of the South China Sea and corresponding geochemical characteristics, provided information on the site-specific evolution of methane seepage dynamics and associated biogeochemical processes. According to the lines of evidence described above, three methane release events (MREs) were recognized: MRE $1,260-300 \mathrm{~cm}$, which corresponds to the longest and most recent period of anaerobic oxidation of methane, associated with high TS contents and precipitation of carbonate phases having depleted carbon isotopic signatures; MRE 2,380-420 cm, which corresponds to a former SMTZ associated with high TS and CRS contents probably indicative of a relatively long duration of methane release and high methane flux; and MRE 3, 480-520 cm, which correspond to another fossil SMTZ horizon, probably related, as inferred from sulfur isotopic composition of sulfide phases, to a short period of methane seepage activity and relatively low methane flux. Overall, this study reveals that the combined application of carbon and sulfur isotopes to cold seep sediments have the potential for reconstructing the temporal variation of methane flux and associated biogeochemical processes. An integrated use of various geochemical indicators can ensure complete recognition of individual events of intense anaerobic oxidation of methane (or methane release events) related to cold seep activity. 


\section{Acknowledgments}

We thank the crew of Haiyang-4 exploration ship for sample collection. Funding was provided by the National Key R\&D Program of China (2017YFC0306702), the National Program on Global Change and Air-Sea Interaction (GASI-GEOGE-05-04), Qingdao National Laboratory for Marine Science and Technology (QNLM2016ORP0204), the NSF of China (Grants: 41730528, 41761134084 and 41773091) and the National Special Project on Gas Hydrate of China (Grant: DD20160217). We thank the guest editor Prof. X.M. Sun and anonymous reviewers for constructive comments, which considerably improved the quality of the manuscript.

\section{References}

Aharon, P., Schwarcz, H.P., Roberts, H.H., 1997. Radiometric dating of submarine hydrocarbon seeps in the Gulf of Mexico. Geol. Soc. Am. Bull. 109, 568-579.

Bayon, G., Pierre, C., Etoubleau, J., Voisset, M., Cauquil, E., Marsset, T., Sultan, N., Drezen, E. Le, Fouquet, F., 2007. Sr/Ca and Mg/Ca ratios in Niger delta sediments: implications for authigenic carbonate genesis in cold seep environments. Mar. Geol. 241, 93-109.

Bayon, G., Henderson, G.M., Bohn, M., 2009. U-Th stratigraphy of a cold seep carbonate crust. Chem. Geol. 260, 47-56.

Bayon, G., Dupre, S., Ponzevera, E., Etoubleau, J., Cheron, S., Pierre, C., Mascle, J., 
Boetius, A., de Lange, G.J., 2013. Formation of carbonate chimneys in the Mediterranean Sea linked to deep-water oxygen depletion. Nat. Geosci. 6, $755-760$.

Bayon, G., Henderson, G.M., Etoubleau, J., Caprais, J.C., Ruffine, L., Marsset, T., Dennielou, B., Cauquil, E., Voisset, M., Sultan, N., 2015. U-Th isotope constraints on gas hydrate and pockmark dynamics at the Niger delta margin. Mar. Geol. 370, 87-98.

Berner, R.A., 1970. Sedimentary pyrite formation. Am. J. Sci. 268, 1-23.

Berner, R.A., 1982. Burial of organic carbon and pyrite sulfur in the modern ocean: its geochemical and environmental significance. Am. J. Sci. 282, 451-473.

Berner, R.A., 1984. Sedimentary pyrite formation: an update. Geochim. Cosmochim. Acta 48, 605-615.

Berner, R.A., 1989. Biogeochemical cycles of carbon and sulfur and their effect on atmospheric oxygen over phanerozoic time. Paleogeogr. Paleoclimatol. Paleoecol. $75,97-122$.

Borowski, W.S., Paull, C.K., Ussler, W., 1996. Marine pore-water sulfate profiles indicate in situ methane flux from underlying gas hydrate. Geology 24, 655-658.

Borowski, W.S., Rodriguez, N.M., Paull, C.K., Ussler, W., 2013. Are 34S-enriched authigenic sulfide minerals a proxy for elevated methane flux and gas hydrates in the geologic record? Mar. Petrol. Geol. 43, 381-395.

Böttcher, M. E., Khim, B. K., Suzuki, A., Gehre, M., Wortmann, U. G., Brumsack, H. J., 2004. Microbial sulfate reduction in deep sediments of the southwest pacific 
(ODP Leg 181, Sites 1119-1125): evidence from stable sulfur isotope fractionation and pore water modeling. Mar. Geol. 205, 249-260.

Bottrell, S. H., Mortimer, R. J. G., Davies, I. M., Harvey, S. M., Krom, M. D., 2009. Sulphur cycling in organic-rich marine sediments from a scottish fjord. Sedimentology, 56, 1159-1173.

Campbell, K.A., Farmer, J.D., Des Marais, D., 2002. Ancient hydrocarbon seeps from the Mesozoic convergent margin of California: carbonate geochemistry, fluids and palaeoenvironments. Geofluids 2, 63-94.

Campbell, K.A., 2006. Hydrocarbon seep and hydrothermal vent paleoenvironments and paleontology: past developments and future research directions. Paleogeogr. Paleoclimatol. Paleoecol. 232, 362-407.

Canfield, D.E., Raiswell, R., Westrich, J.T., Reaves, C.M., Berner, R.A., 1986. The use of chromium reduction in the analysis of reduced inorganic sulfur in sediments and shales. Chem. Geol. 54, 149-155.

Coffin, R. B., Hamdan, L. J., Smith, J. P., Rose, P. S., Plummer, R. E., Yoza, B., Pecher, I., Montgomery, M. T., 2014. Contribution of Vertical Methane Flux to Shallow Sediment Carbon Pools across Porangahau Ridge, New Zealand. Energies 7, 5332-5356.

Dickens G R, 2001. Sulfate profiles and barium fronts in sediment on the Blake Ridge: present and past methane fluxes through a large gas hydrate reservoir. Geochim. Cosmochim. Acta 65, 529-543.

Feng, D., Birgel, D., Peckmann, J., Roberts, H.H., Joye, S.B., Sassen, R., Liu, X.L., 
Hinrichs, K.U., Chen, D.F., 2014. Time integrated variation of sources of fluids and seepage dynamics archived in authigenic carbonates from Gulf of Mexico gas hydrate seafloor observatory. Chem. Geol. 385, 129-139.

Feng, D., Cheng, M., Kiel, S., Qiu, J.W., Yang, Q., Zhou, H., Peng, Y.B., Chen, D.F., 2015a.Using Bathymodiolus tissue stable carbon, nitrogen and sulfur isotopes to infer biogeochemical process at a cold seep in the South China Sea. Deep-Sea Res. I 104, 52-59.

Feng, D., Chen, D., 2015b. Authigenic carbonates from an active cold seep of the northern South China Sea: new insights into fluid sources and past seepage activity. Deep-Sea Res. II 122, 74-83.

Feng, D., Peng, Y., Bao, H., Peckmann, J., Roberts, H. H., Chen, D., 2016. A carbonate-based proxy for sulfate-driven anaerobic oxidation of methane. Geology 44, 999-1002.

Feng, D., Qiu, J.-W., Hu, Y., Peckmann, J., Guan, H., Tong, H., Chen, C., Chen, J., Gong, S., Li, N., Chen, D. Cold seep systems in South China Sea: An overview, J. Asian Earth Sci., 2018. https://doi.org/10.1016/j.jseaes.2018.09.021.

Freudenthal, T., Wagner, T., Wenzhöfer, F., Zabel, M., Wefer, G., 2001. Early diagenesis of organic matter from sediments of the eastern subtropical Atlantic: evidence from stable nitrogen and carbon isotopes. Geochim. Cosmochim. Acta $65,1795-1808$.

Gong, S., Peng, Y., Bao, H., Feng, D., Cao, X., Crockford, P., Chen, D., 2018. Triple sulfur isotope relationships during sulfate driven anaerobic oxidation of methane. 
Earth Planet. Sci. Lett. 504, 13-20.

Greinert, J., 2008. Monitoring temporal variability of bubble release at seeps: The hydroacoustic swath system GasQuant. J. Geophys. Res. Oceans 113, 827-830.

Han, X., Suess, E., Sahling, H., Wallmann, K., 2004. Fluid venting activity on the Costa Rica margin: new results from authigenic carbonates. Int. J. Earth Sci. 93, 596-611.

Han, X.Q., Suess, E., Huang, Y.Y., Wu, N.Y., Bohrrnann, G., Su, X., Eisenhauer, A., Rehder, G., Fang, Y.X., 2008. Jiulong methane reef: Microbial mediation of seep carbonates in the South China Sea. Mar. Geol. 249, 243-256.

Han, X., Suess, E., Liebetrau, V., Eisenhauer, A., Huang, Y., 2014. Past methane release events and environmental conditions at the upper continental slope of the South China Sea: constraints by seep carbonates. Int. J. Earth Sci. 103, $1873-1887$.

Hiruta, A., Klügel, A., Matsumoto, R., 2016. Increase in methane flux and dissociation of iron and manganese oxides recorded in a methane-derived carbonate nodule in the eastern margin of the Sea of Japan. Georesj 9-12, $104-116$.

Holmer, M., Storkholm, P., 2001.Sulphate reduction and sulphur cycling in lake sediments: a review. Freshw. Biol. 46, 431-451.

Hu, Y., Feng, D., Liang, Q., Xia, Z., Chen, L., Chen, D., 2015. Impact of anaerobic oxidation of methane on the geochemical cycle of redox-sensitive elements at cold-seep sites of the northern South China Sea. Deep-Sea Res. II 122, 84-94. 
Hu, Y., Luo, M., Liang, Q., Chen, L., Feng, D., Yang, S., Liang, J., Chen, D. Pore fluid compositions at the Haima cold seeps in the South China Sea:

Methane-related carbon cycling and its implications for carbon sources at paleoseeps. Mar. Petrol. Geol. (in revision).

Jørgensen, B.B., 1982. Mineralization of organic matter in the sea bed — the role of sulfate reduction. Nature 296, 643-645.

Jørgensen, B.B., Weber, A., Zopfi, J., 2001. Sulfate reduction and anaerobic oxidation in Black Sea sediments. Deep-Sea Res. I 48, 2097-2120.

Jørgensen, B.B., Böttcher, M. E., Lüschen, H., Neretin, L.N., Volkov I. I., 2004. Anaerobic methane oxidation and a deep $\mathrm{H} 2 \mathrm{~S}$ sink generate isotopically heavy sulfides in Black Sea sediments. Geochim. Cosmochim. Acta 68, 2095-2118.

Jørgensen, B.B., Parkes, R.J., 2010. Role of sulfate reduction and methane production by organic carbon degradation in eutrophic fjord sediments (Limfjorden, Denmark). Limnol. Oceanogr. 55, 1338-1352.

Judd, A.G., Hovland, M., Dimitrov, L.I., García Gil, S., Jukes, V., 2002. The geological methane budget at continental margins and its influence on climate change. Geofluids 2, 109-126.

Karaca, D., Hensen, C., Wallmann, K., 2010. Controls on authigenic carbonate precipitation at cold seeps along the convergent margin off Costa Rica. Geochem. Geophys. Geosyst. 11, Q08S27. http://dx.doi.org/10.1029/2010GC003062.

Kvenvolden, K.A., 1988. Methane hydrates and global climate. Glob. Biogeochem. Cycle 2, 221-229. 
Kvenvolden, K.A., 1993. Gas hydrate-geological perspective and global change. Rev. Geophys. 31, 173-187.

Lehmann, M.F., Bernasconi, S.M., Barbieri, A., Mckenzie, J.A., 2002. Preservation of organic matter and alteration of its carbon and nitrogen isotope composition during simulated and in situ early sedimentary diagenesis. Geochim. Cosmochim. Acta 66, 3573-3584.

Liang, Q., Hu, Y., Feng, D., Peckmann, J., Chen, L., Yang, S., Liang, J., Tao, J., Chen, D., 2017.Authigenic carbonates from newly discovered active cold seeps on the northwestern slope of the South China Sea: Constraints on fluid sources, formation environments, and seepage dynamics. Deep-Sea Res. I 124, 31-41.

Lim, Y.C., Lin, S., Yang, T.F., Chen, Y.G., Liu, C.S., 2011. Variations of methane induced pyrite formation in the accretionary wedge sediments offshore southwestern Taiwan. Mar. Petrol. Geol. 28, 1829-1837.

Li, N., Feng, D., Chen, L., Wang, H., Chen, D., 2016. Using sediment geochemistry to infer temporal variation of methane flux at a cold seep in the South China Sea. Mar. Petrol. Geol. 77, 835-845.

Lin, Q., Wang, J.S., Taladay, K., Lu, H.F., Hu, G.W., Sun, F., Lin, R.X., 2016. Coupled pyrite concentrations and sulfur isotopic insight into the paleo sulfate-methane transition zone (SMTZ) in the northern South China Sea. J. Asian Earth Sci. 115, 547-556.

Lin, Z., Sun, X., Peckmann, J., Yang, L., Li, X., Strauss, H., Zhou, H., Gong, J., Lu, H., Teichert, B., 2016. How sulfate-driven anaerobic oxidation of methane 
affects the sulfur isotopic composition of pyrite: a sims study from the south china sea. Chem. Geol. 440, 26-41.

Luff, R., Wallmann, K., 2003. Fluid flow, methane fluxes, carbonate precipitation and biogeochemical turnover in gas hydrate-bearing sediments at Hydrate Ridge, Cascadia Margin: Numerical modeling and mass balances. Geochim. Cosmochim. Acta 67, 3403-3421.

Luff, G., Wallmann, K., Aloisi, G., 2004. Numerical modeling of carbonate crust formation at cold vent sites: significance for fluid and methane budgets and chemosynthetic biological communities. Earth Planet. Sci. Lett. 221, 337-353.

Luo, M., Chen, L., Wang, S., Yan, W., Wang, H., Chen, D. 2013. Pockmark activity inferred from pore water geochemistry in shallow sediments of the pockmark field in southwestern Xisha Uplift, northwestern South China Sea. Mar. Petrol. Geol. 48, 247-259.

Maciej, B., 2012. Geochemical paleogradient in pore waters controlled by AOM recorded in an Oligocene laminated limestone from the Outer Carpathians. Chem. Geol. 292, 45-56.

Mazumdar, A., Dewangan, P., Joäo, H., Peketi, A., Khosla, V., Kocherla, M., Badesab, F., Joshi, R., Roxanne, P., Ramamurty, P., 2009. Evidence of paleo-cold seep activity from the Bay of Bengal, offshore India. Geochem. Geophys. Geosyst. 10, $329-332$.

Mazumdar, A., Joshi, R.K., Peketi, A., Kocherla, M., 2011. Occurrence of faecal pellet-filled simple and composite burrows in cold seep carbonates: a glimpse of 
a complex benthic ecosystem. Mar. Geol. 289, 117-121.

Meyers, P.A., 1994. Preservation of elemental and isotopic source identification of sedimentary organic-matter. Chem. Geol. 114, 289-302.

Meyers, P.A., 1997. Organic geochemical proxies of palaeoceanographic, palaeolimnologic and paleoclimatic processes. Org. Geochem. 27, 213-250.

Nauhaus, K., Treude, T., Boetius, A., Krüger, M., 2005. Environmental regulation of the anaerobic oxidation of methane: a comparison of ANME-I and ANME-II communities. Environ. Microbiol. 7, 98-106.

Niewohner, C., Henson, C., Kasten, S., Zabel, M., Schultz, H.D., 1998.Deep sulfatereduction completely mediated by anaerobic methane oxidation in sediments ofthe upwelling area off Nambia. Geochim. Cosmochim. Acta 62, $455-464$.

Ogrinc, N., Fontolan, G., Faganeli, J., Covelli, S., 2005. Carbon and nitrogen isotope compositions of organic matter in coastal marine sediments (the Gulf of Trieste, N Adriatic Sea): indicators of sources and preservation. Mar. Chem. 95, $163-181$.

Peckmann. J, Thiel. V., 2004. Carbon cycling at ancient methane seeps. Chem. Geol. 205, 443-467.

Peketi, A., Joshi, R. K., Patil, D. J., Srinivas, P. L., Dayal, A. M. 2012. Tracing the paleo sulfate-methane transition zones and $\mathrm{H}_{2} \mathrm{~S}$ seepage events in marine sediments: an application of C-S-Mo systematics. Geochem. Geophys. Geosyst. $13,163-183$. 
Peketi, A., Mazumdar, A., Joao, H. M., Patil, D. J., Usapkar, A., Dewangan, P. 2015. Coupled C-S-Fe geochemistry in a rapidly accumulating marine sedimentary system: Diagenetic and depositional implications. Geochem. Geophys. Geosyst. $16,2865-2883$.

Raven M., Sessions A., Fischer W., Adkins J., 2016. Sedimentary pyrite $\delta^{34}$ S differs from porewater sulfide in Santa Barbara Basin: Proposed role of organic sulfur. Geochim. Cosmochim. Acta 186, 120-134.

Sato, H., Hayashi, K., Ogawa, Y., Kawamura, K., 2012. Geochemistry of deep sea sediments at cold seep sites in the Nankai Trough: insights into the effect of anaerobic oxidation of methane. Mar. Geol. 323, 47-55.

Schneider von Deimling, J., Rehder, G., Greinert, J., McGinnnis, D.F., Boetius, A., Linke, P., 2011.Quantification of seep-related methane gas emissions at Tommeliten, North Sea. Cont. Shelf Res. 31, 867-878.

Solomon, E. A., Kastner, M., Jannasch, H., Robertson, G., Weinstein, Y., 2008. Dynamic fluid flow and chemical fluxes associated with a seafloor gas hydrate deposit on the northern Gulf of Mexico slope. Earth Planet. Sci. Lett. 270, $95-105$.

Suess, E., 2014. Marine cold seeps and their manifestations: Geological control, biogeochemical criteria and environmental conditions. Int. J. Earth Sci. 103, 1889-1916.

Teichert, B.M.A., Eisenhauer, A., Bohrmann, G., Haase-Schramm, A., Bock, B., Linke, P., 2003. U/Th Systematics and ages of authigenic carbonates from 
hydrate ridge, Cascadia margin: recorders of fluid flow variations. Geochim. Cosmochim. Acta 67, 3845-3857.

Tesi, T., Miserocchi, S., Goñi, M. A., Langone, L., Boldrin, A., Turchetto, M., 2007. Organic matter origin and distribution in suspended particulate materials and surficial sediments from the western Adriatic Sea (Italy). Estuar. Coast. Shelf Sci. $73,431-446$.

Tong, H., Feng, D., Cheng, H., Yang, S.X., Wang, H.B., Min, A.G., Edwards, R.L., Chen, Z., Chen, D.F., 2013. Authigenic carbonates from seeps on the northern continental slope of the South China Sea: new insights into fluid sources and geochronology. Mar. Petrol. Geol. 43, 260-271.

Tribovillard, N., Algeo, T.J., Lyons, T., Riboulleau, A., 2006. Trace metals as paleoredox and paleoproductivity proxies: An update. Chem. Geol. 232, 12-32.

Tribovillard, N., Algeo, T.J., Baudin, F., Riboulleau, A., 2012. Analysis of marine environmental conditions based on molybdenum-uranium covariation-Applications to Mesozoic paleoceanography. Chem. Geol. 324, 46-58.

Tribovillard, N., du Chatelet, E.A., Gay, A., Barbecot, F., Sansjofre, P., Potdevin, J.L., 2013. Geochemistry of cold seepage-impacted sediments: Per-ascensum or per-descensum trace metal enrichment? Chem. Geol. 340, 1-12.

Wang, X., Chen, R., Zhao, Q., Chen, J., Ran, L., Wiesner, M.G., 2014. The influence of east Asian monsoon on seasonal variations in planktonic foraminiferal flux and stable isotope in the northern south china sea during 2009-2010. Marine 
Geology \& Quaternary Geology 34, 103-115 (in Chinese with English abstract).

Wankel, S. D., Joye, S. B., Samarkin, V. A., Shah, S. R., Friederich, G., Melas-Kyriazi, J., Girguis, P. R., 2010. New constraints on methane fluxes and rates of anaerobic methane oxidation in a Gulf of Mexico brine pool via in situ, mass spectrometry. Deep-Sea Res. II 57, 2022-2029.

Whiticar, M.J., 1999. Carbon and hydrogen isotope systematics of bacterial formation and oxidation of methane. Chem. Geol. 161, 291-314.

Wijsman, J.W.M., Middleburg, J.J., Herman, P.M.J., Böttcher, M.E., Heip, C.H.R., 2001.Sulfur and iron speciation in surface sediments along the northwestern margin of the Black Sea. Mar. Chem. 74, 261-278.

Wilkin, R.T., Barnes, H.L., 1996. Pyrite formation by reactions of iron monosulfides with dissolved inorganic and organic sulfur species. Geochim. Cosmochim. Acta $60,4167-4179$.

Ye, Y., Liu, Z.Q., Chen, N.H., Tu, X.X., 2004.Oxygen and carbon isotopes of planktonic foraminifera in surface sediments of the South China Sea and their oceanographic implications. Journal of Zhejiang University (Science Edition) 31, 114-120 (in Chinese).

Zhu, W., Huang, B., Mi, L., Wilkins, R. W. T., Fu, N., Xiao, X., 2009. Geochemistry, origin, and deep-water exploration potential of natural gases in the Pearl River Mouth and Qiongdongnan Basins, South China Sea. AAPG Bull. 93, 741-761. 


\section{Figure captions}

Figure 1. Map showing the location of the sediment cores collected for this study (modified from Liang et al., 2017).

Figure 2. (A) Depth profiles of pore water $\mathrm{SO}_{4}{ }^{2-}, \mathrm{Mg}^{2+}, \mathrm{Ca}^{2+}$, DIC concentrations and $\delta^{13} \mathrm{C}_{\mathrm{DIC}}$ values of the three cores (Data of QDN-14A and QDN-14B are from $\mathrm{Hu}$ et al., 2018); (B) Depth profiles of sediment total organic carbon (TOC), total inorganic carbon (TIC), total nitrogen (TN) and total sulfur (TS) in the three cores. The carbon/nitrogen $(\mathrm{C} / \mathrm{N})$ molar ratios and carbon/sulfur $(\mathrm{C} / \mathrm{S})$ ratios are also shown. Shaded horizontal bars indicate events of methane seepage.

Figure 3. (A) Depth distribution of chromium reducible sulfur (CRS; A) and its sulfur isotopic composition $\left(\delta^{34} \mathrm{~S}_{\mathrm{CRS}} ; \mathrm{B}\right)$. Shaded horizontal bars indicate events of methane seepage.

Figure 4. Depth profiles of the median particle diameter for core QDN-14B and QDN-31.

Figure 5. (A) Depth profiles of sediment acid-insoluble sediments carbon $\left(\delta^{13} \mathrm{C}_{\text {organic }}\right.$ carbon; $\mathrm{A})$ and sulfur $\left(\delta^{34} \mathrm{~S}_{\text {acid-insoluble; }}\right.$ B) isotopic composition of the Core QDN-14B and QDN-31. Shaded horizontal bars indicate events of methane seepage.

Figure 6. (A) The carbon and oxygen isotope compositions of dissolved inorganic carbon in the bulk sediment of the core QDN-14A. Shaded horizontal bars indicate events of methane seepage. (B) Plot showing the correlation of the carbon and oxygen isotope compositions of dissolved inorganic carbon in the bulk sediment core QDN-14A. Shaded horizontal bars indicate $\delta^{13} \mathrm{C}$ and $\delta^{18} \mathrm{O}$ data of 
planktonic foraminifera gained from sediments of northern South China Sea (Ye et al., 2004; Wang et al., 2014).

Figure 7. Conceptual model showing the utility of geochemical indicators of sediments with different methane flux and duration, in which the location of SMTZ represents the position where AOM action occurred at that time. MRE 1: this event of methane seepage is persistent and under intermediate to high methane flux. Therefore, the authigenic carbonates precipitated, resulting in low $\delta^{13} \mathrm{C}_{\mathrm{TIC}}$ value, while $\mathrm{Fe}$ combined with hydrogen sulfide that generated through AOM and formed pyrite, which causes the TS-rich level; MRE 2: the methane flux of this event is high, which cause the SMTZ is very shallow. Meanwhile, relative long-term seepage lead to the $\mathrm{HS}^{-}$generated and accordingly the accumulation of sulfide; MRE 3: the methane flux of this event is low, thus the methane reacts with sulfate in the deep part of the sediment, and the depth of SMTZ is accordingly deeper. During this event, methane is continuously anaerobic oxidized by sulfate, the residual sulfate after the previous AOM process can be re-reduced so that the pyrite inherits the relatively positive isotopic characteristic. Arrow sizes are proportional to downward sulfate and upward methane fluxes. SWI: sediment-water interface; SMTZ: sulfate-methane transition zone.

\section{Table captions}

Table S1. Depth distribution of pore water $\mathrm{SO}_{4}{ }^{2-}, \mathrm{Mg}^{2+}, \mathrm{Ca}^{2+}$ concentrations of the 
reference site (QDN-31).

Table S2. Depth distribution of total organic carbon (TOC), total inorganic carbon (TIC), total nitrogen (TN) and total sulfur (TS) expressed in weight percent (wt.\%) of the core QDN-14A, QDN-14B, and QDN31. Also shown are carbon/nitrogen $(\mathrm{C} / \mathrm{N})$ molar ratios and carbon/sulfur $(\mathrm{C} / \mathrm{S})$ ratios.

Table S3. Depth distribution of chromium reducible sulfur (CRS) and its sulfur isotopic composition $\left(\delta^{34} \mathrm{~S}_{\mathrm{CRS}}\right)$, median particle diameter, $\delta^{13} \mathrm{C}_{\text {organic carbon }}$ and $\delta^{34} S_{\text {acid-insoluble }}$ of sediment after acid soluble of the core QDN-14B and QDN-31.

Table S4. The carbon and oxygen isotopic compositions of dissolved inorganic carbon in the bulk sediment of the core QDN-14A. 


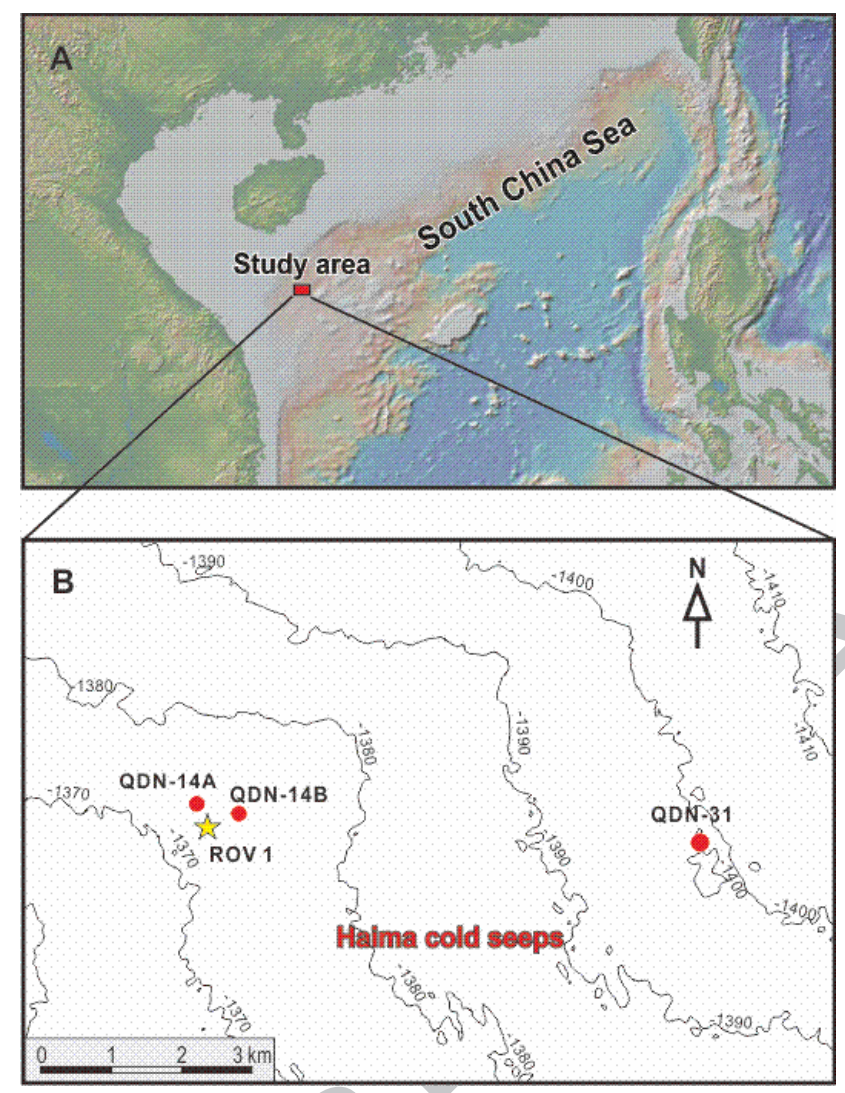



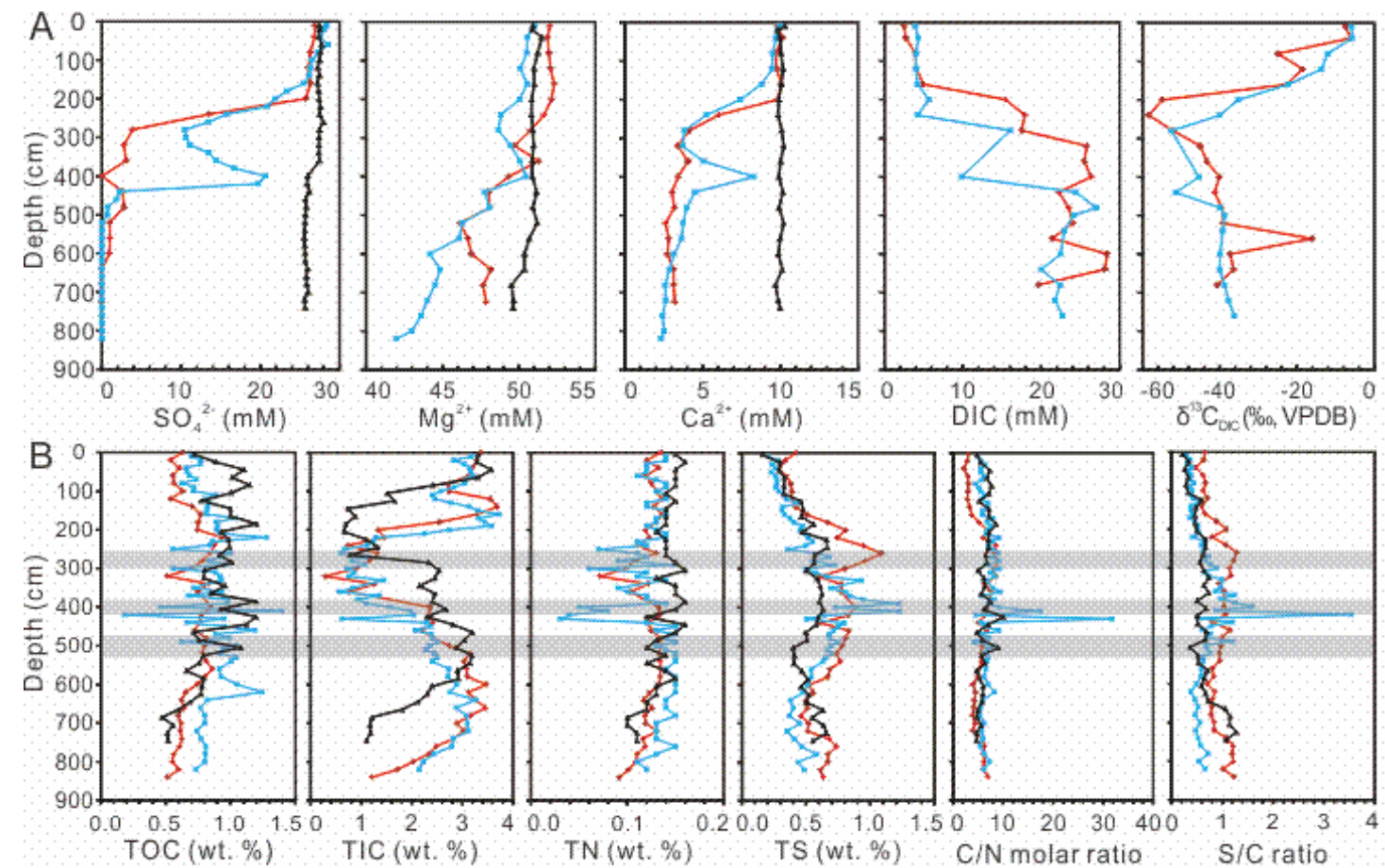

$\rightarrow$ QDN-14A

$\because \mathrm{QDN}-14 \mathrm{~B}$

$\rightarrow$ QDN-31

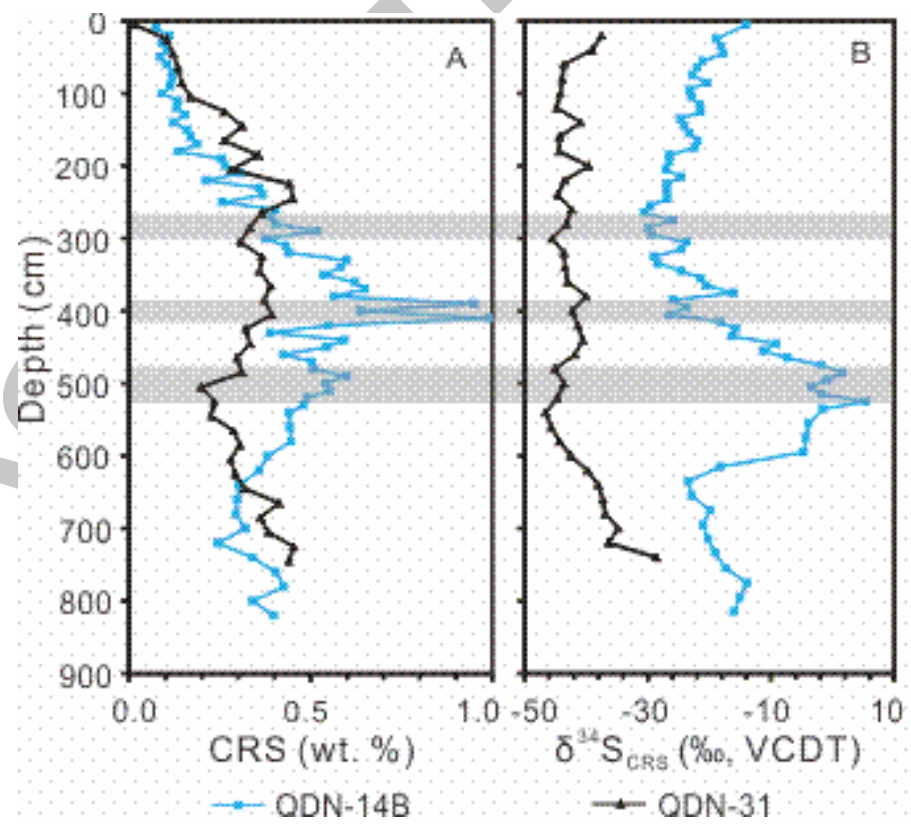




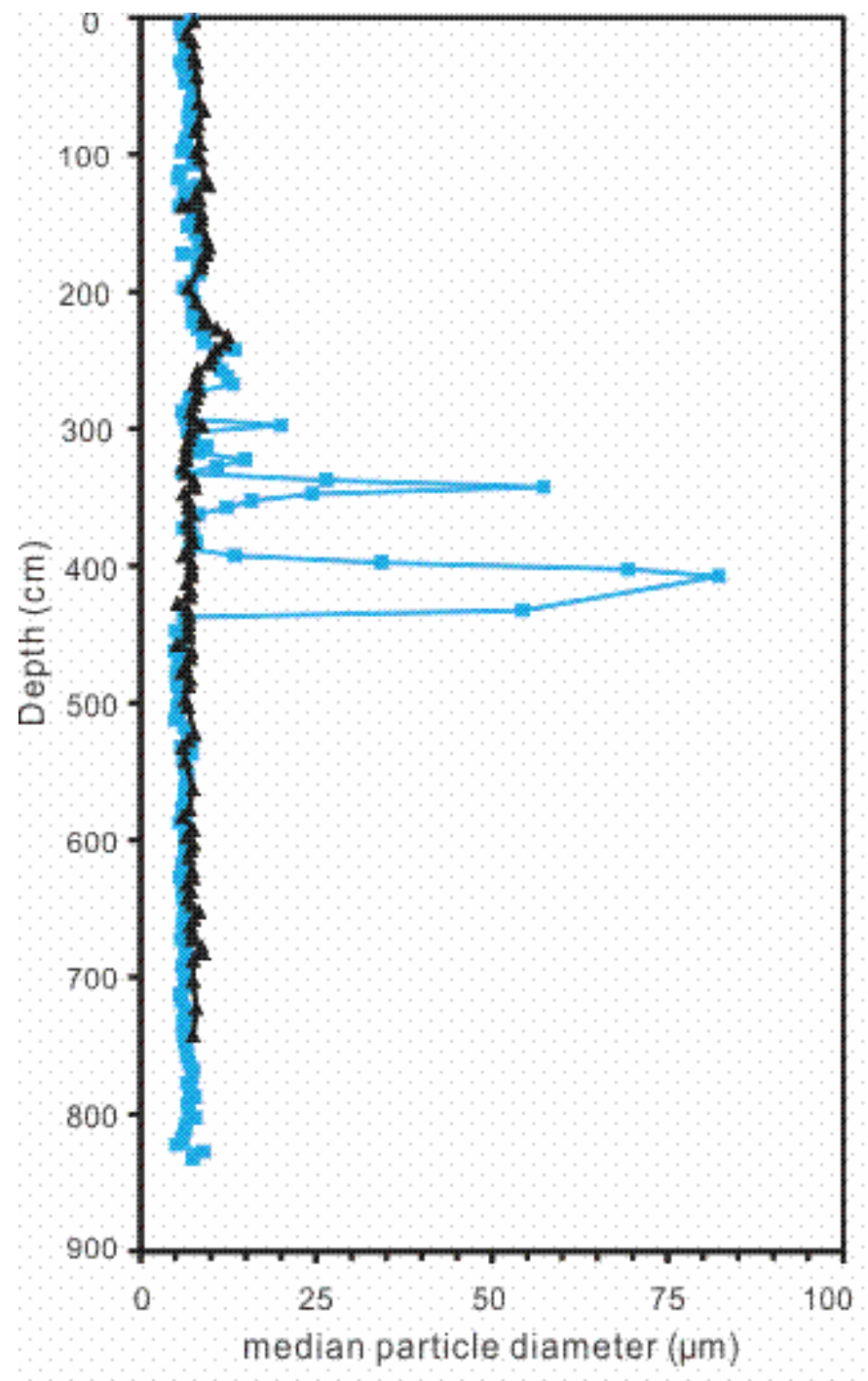

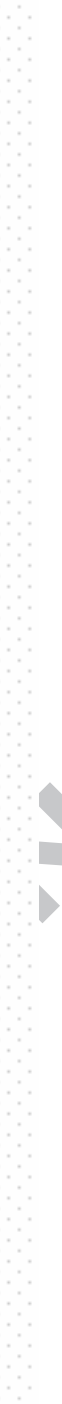

- ODN14B - ODN 31 


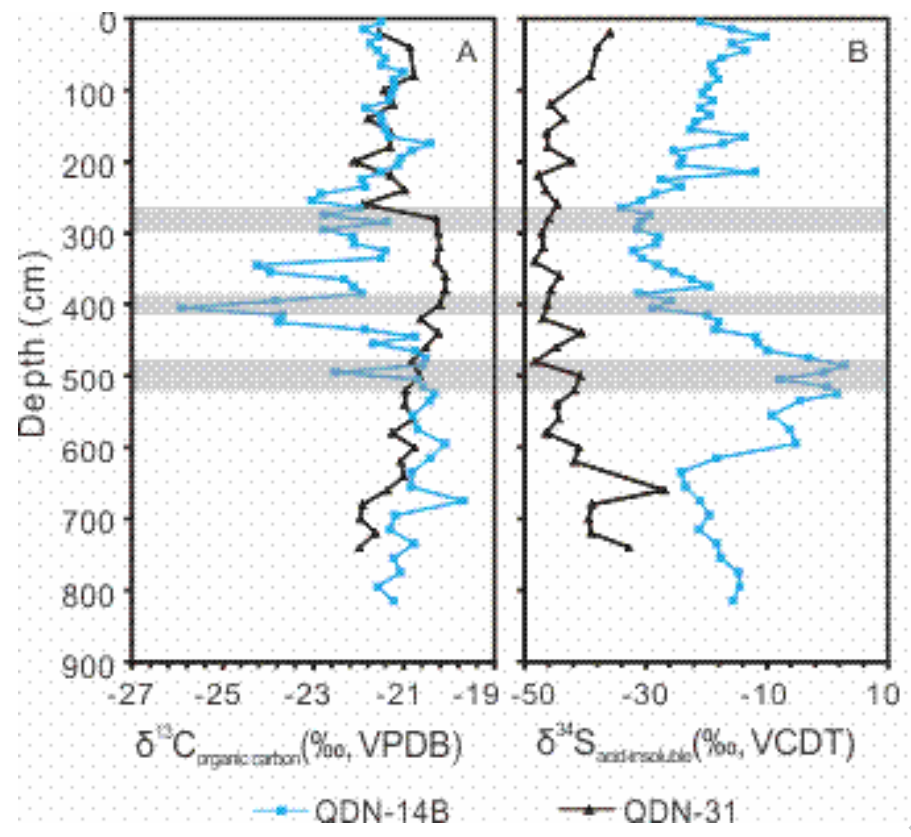

A $\quad \delta^{13} \mathrm{C}(\%$, VPDB $) \rightarrow$

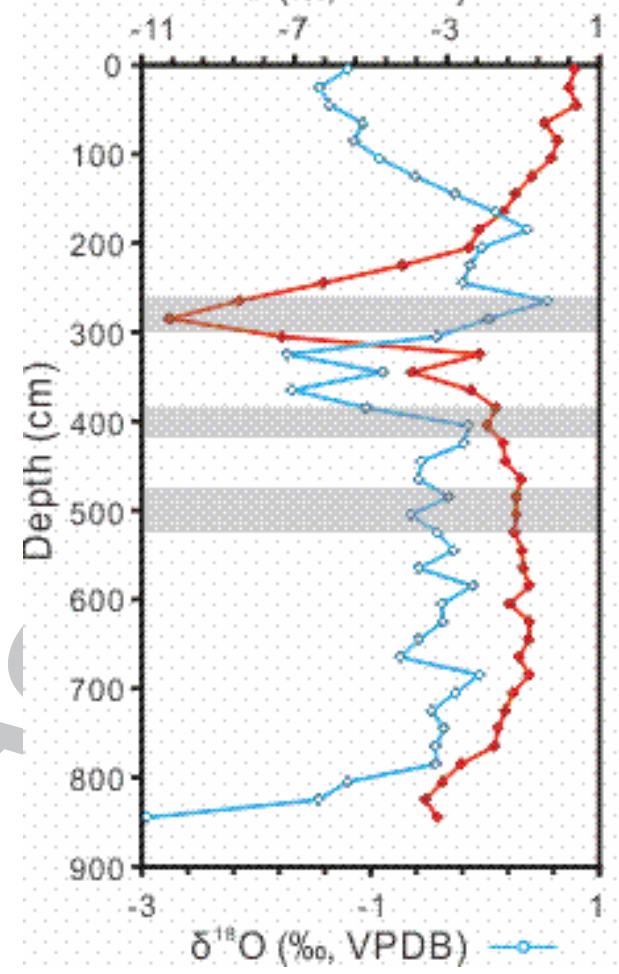

$\mathrm{B}$

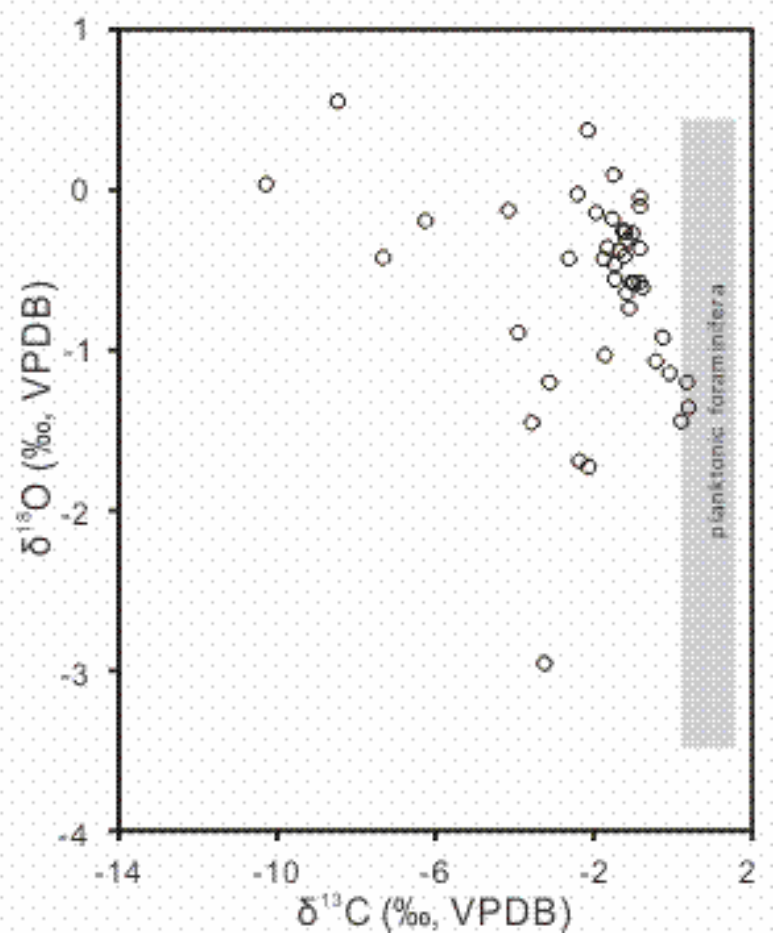




\begin{tabular}{|c|c|c|}
\hline $\begin{array}{l}\text { MRE 1: most long-term } \\
\text { SWI }\end{array}$ & $\begin{array}{l}\text { MRE 2: relative long-term } \\
\text { SWI }\end{array}$ & $\begin{array}{l}\text { MRE 3: short-term } \\
\text { SWI }\end{array}$ \\
\hline $1 \mathrm{HS} \backslash \mathrm{SO}_{4}^{2}$ & $\begin{array}{ll}\mathrm{CHS} & \mathrm{H} \\
\mathrm{SMTZ} & \mathrm{O}\end{array}$ & \multirow[b]{3}{*}{$\$ \mathrm{SO}_{4}^{2} \mathrm{HS}$} \\
\hline$S M T Z \sim 9-1$ & \multirow[t]{4}{*}{ HS } & \\
\hline \multirow{3}{*}{$\mathrm{CH}_{4}$} & & \\
\hline & & 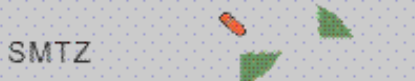 \\
\hline & & $7 \mathrm{HS} \quad \mathrm{A} \mathrm{CH}_{4}$ \\
\hline \multicolumn{3}{|c|}{ evidence of seepage } \\
\hline $\mathrm{TS} \uparrow \quad \delta^{\mathrm{IS}} \mathrm{C}$ rid & TS $\uparrow \quad C R S \uparrow$ & 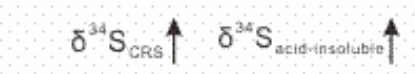 \\
\hline
\end{tabular}


Highlights

- Sediments from Haima cold seeps have variable compositions.

- $\mathrm{AOM}$ caused high $\delta^{34} \mathrm{~S}_{\mathrm{CRS}}$ and low $\delta^{13} \mathrm{C}_{\mathrm{TIC}}$ values, and high CRS contents.

- AOM indicators of sediments are variable under variable methane flux and duration.

- Three methane release events were identified in the seep site. 
Graphical abstract

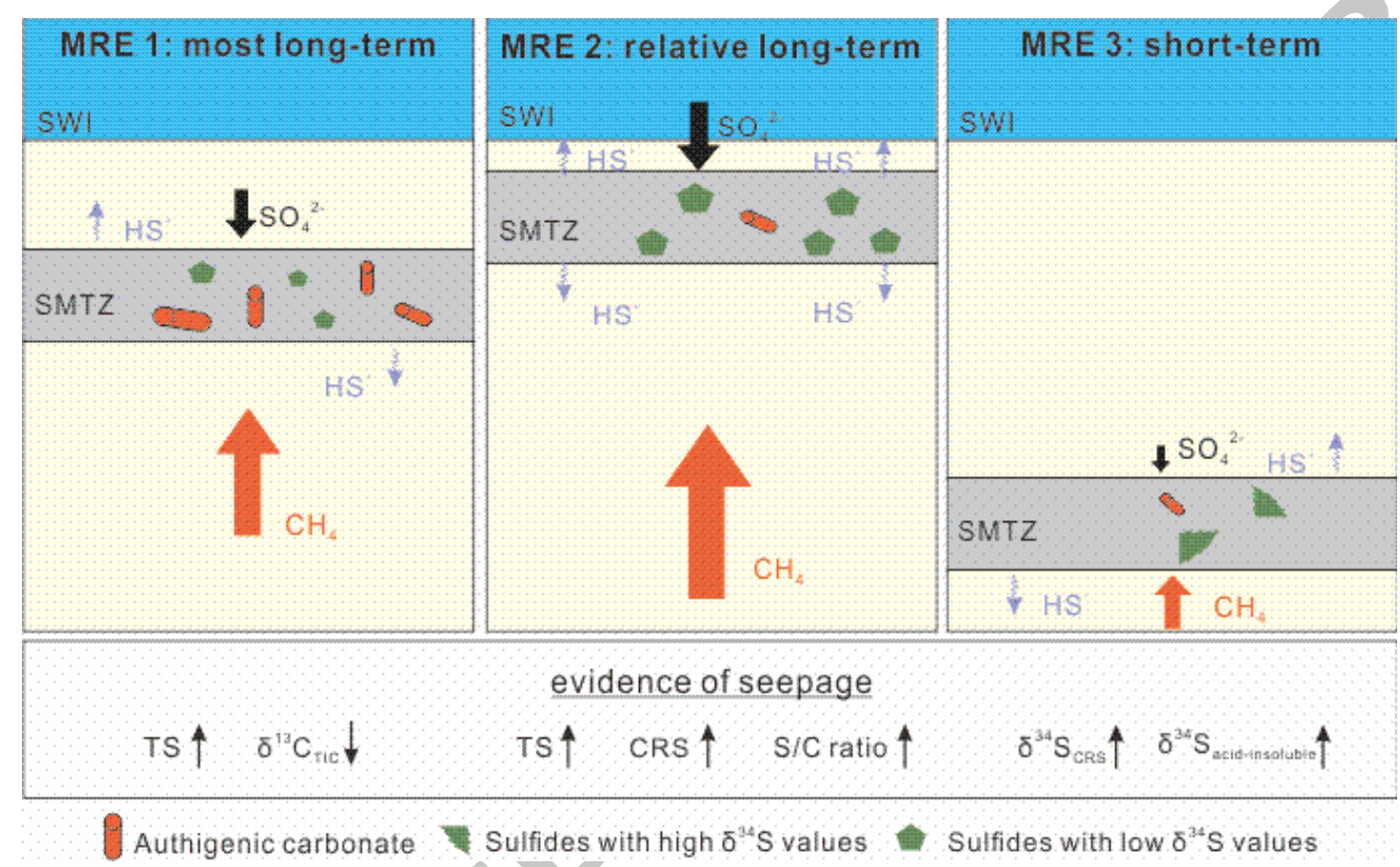

